\title{
Determinants of Early Initiation of Breastfeeding in Lamongan Public Health Center
}

\author{
Husnul Muthoharoh* \\ Vocational Program of Midwifery, Lamongan Islamic University, East Java, Indonesia \\ *ques.muth@gmail.com
}

\begin{abstract}
The World Health Organization (WHO) and United Nations Children's Fund (UNICEF) recommend initiation of breastfeeding within the first hour of life. This research aimed to investigated the determinants of breastfeeding practices in Lamongan Public Health Center. This study used an observational analytic research design with a cross-sectional approach. The population in this study were all mothers giving birth at the Lamongan Public Health Center when the study was running in May-July 2020. The sampling technique used total sampling. The sample in this study are 43 people. The factors associated with the implementation of early breastfeeding initiation were knowledge about early initiation of breastfeeding ( $\mathrm{p}$ value $=0.000)$ and family support $(\mathrm{p}$ value $=0.006)$. It is recommended that childbirth service providers provide education to families before childbirth in order to facilitate the implementation of early initiation of breastfeeding.
\end{abstract}

Keywords : Early Initiation Of Breastfeeding, Family Support, Knowledge 


\section{STRADA Jurnal Ilmiah Kesehatan}

DOI: $10.30994 /$ sjik.v9i2.443

ISSN: 2252-3847 (print); 2614-350X (online)

Vol.9 No.2 November 2020 Page.1151-1159

\section{BACKGROUND}

Globally, about 800,000 neonatal deaths are due to late initiation of breastfeeding and lack of exclusive breastfeeding. Early initiation of breastfeeding after birth can reduce the risk of neonatal death in the first week of life by 22\% globally (Bbaale, 2014). According to the recently updated Evidence Based Protocol by the world health organizations and PBB organizations that provide humanitarian assistance and long-term welfare development to children and mothers in developing countries, it is stated that the risk of infant mortality between 9-12 months increases by $40 \%$ if not breastfed at 6 developing country. The mortality rate will increase to $48 \%$ for babies under 2 months. With early initiation of breastfeeding the mortality rate for infants aged 28 days can be reduced by $22 \%$ and the under-five mortality rate by $8.8 \%$. Breastfeeding is one of the efforts made to accelerate the decrease in IMR. One of the factors that influence the sustainability of breastfeeding is early initiation of breastfeeding (Muthoharoh, 2018). Early Initiation of Breastfeeding is a program issued by WHO and UNICEF in 2007. The way babies do Early Initiation of Breastfeeding is called the breast crawl or crawling looking for breasts (Sukarti et al., 2020).

Early initiation of breastfeeding is the process of allowing a baby on his own instinct to breastfeed as soon as within the first hour after birth, along with contact between the baby's skin and the mother's skin (Asmarani, 2019). The causes of neonatal mortality were $36 \%$ infection, $28 \%$ prematurity, and $23 \%$ asphyxia. One way that can be done to increase neonatal immunity is to provide colostrum as soon as possible to newborns containing immunoglobulin A (IgA) which helps coat the intestines of infants who are still young and prevent germs from entering the baby's intestines through early initiation of breastfeeding (Ali et al., 2020). Early initiation of breastfeeding should be done immediately when the baby is born without being delayed by weighing or measuring the baby. In order to achieve success in early initiation of breastfeeding, it takes time and the process takes place skin to skin between the baby and the mother (Sulistianingsih, 2020).

Early initiation of breastfeeding provides many health benefits for both mother and newborn. Benefits for Early Initiation of Breastfeeding mothers are proven to be able to increase levels of the hormone oxytocin and accelerate uterine involution 2 hours post partum and shorten the time to release the placenta so that it can prevent post partum hemorrhage, which is one of the biggest causes of maternal death worldwide, including Indonesia. Five benefits for babies according to several research on breastfeeding immediately within the first hour of birth can prevent infant mortality in the first month by up to $22 \%$ while breastfeeding on the first day of birth (24 hours) can reduce infant mortality by up to $16 \%, 6$ prevent mortality in infants with Low Birth Weight (LBW), and prevent death from diarrhea and pneumonia, which are the main causes of infant mortality (Faisal, Joserizal and Hirowati, 2019)

Early initiation of breastfeeding implementation is strongly influenced by several things, both from the internal factor of the mother who gives birth which is the basic factor for implementing early initiation of breastfeeding. Such as mother's knowledge, mother's attitudes, beliefs, traditions of the mother, as well as external factors which are the supporting and driving factors for the implementation of early initiation of breastfeeding. Such as the availability and affordability of resources (health workers and health facilities and infrastructure) as well as support from those closest to them such as husbands or families (Muthoharoh, 2017). All of these components greatly contribute to the implementation of early breastfeeding initiation, allegedly because until now there is still a lack of counseling and other health promotion activities related to early initiation of 


\section{STRADA Jurnal Ilmiah Kesehatan}

DOI: $10.30994 /$ sjik.v9i2.443

ISSN: 2252-3847 (print); 2614-350X (online)

Vol.9 No.2 November 2020 Page.1151-1159

breastfeeding so that it can affect the knowledge and attitudes of mothers towards early initiation of breastfeeding (Sari and Ambarwati, 2020). In addition, not all health workers who assist in childbirth apply the early initiation of breastfeeding process to mothers who give birth and support from families, especially husbands, is lacking for mothers to carry out early initiation of breastfeeding (Bbaale, 2014).

\section{METHODS}

This study used an observational analytic research design with a cross-sectional approach. The population in this study were all women who gave birth at the Lamongan Health Center at the time of the research. The sample in this study amounted to 43 people who met the inclusion and exclusion criteria. This research was conducted in May-July 2020. The sampling technique in this study used a total sampling technique. Measuring instruments in this study researchers used instruments such as: Sheet A for the identity of the respondent, to determine the characteristics of the respondent. Sheet B of the observation sheet to determine the implementation of early initiation of breastfeeding and Colostrum expenditure. Data were analyzed using frequency distribution and chi square statistical test.

\section{RESULTS}

\section{Univariate Analysis}

a. Age

The frequency distribution by age group can be seen in the following table:

Table 1.Distribution of Characteristics of Respondents by Age at Puskesmas Lamongan $(n=43)$

\begin{tabular}{ccc}
\hline Age & Frequency & Percentage (\%) \\
\hline$\leq 27$ & 19 & 44.2 \\
$>27$ & 24 & 55.8 \\
Total & $\mathbf{4 3}$ & $\mathbf{1 0 0}$ \\
\hline
\end{tabular}

Based on the age characteristics in table 2 it can be seen that respondents aged $\leq 27$ years were 19 respondents $(44.2 \%)$ while respondents aged $>27$ years were 24 respondents $(55.8 \%)$.

b. Education

The frequency distribution by education group can be seen in the following table:

Table 2.Frequency Distribution of Respondent Characteristics Based on Education at Lamongan Health Center $(n=43)$

\begin{tabular}{ccc}
\hline Education & Frequency & Percentage (\%) \\
\hline SD & 9 & 20.9 \\
Junior High & 6 & 14.0 \\
High school & 24 & 55.8 \\
PT & 4 & 9.3 \\
Total & $\mathbf{4 3}$ & $\mathbf{1 0 0}$ \\
\hline
\end{tabular}

The education level of the respondents was categorized into four groups, namely SD, SMP, SMA, and PT. Most of the respondents belong to high school education level, namely 24 respondents $(55.8 \%)$. 


\section{STRADA Jurnal Ilmiah Kesehatan}

DOI: $10.30994 /$ sjik.v9i2.443

ISSN: 2252-3847 (print); 2614-350X (online)

Vol.9 No.2 November 2020 Page.1151-1159

c. Profession

The frequency distribution by education group can be seen in the following table:

Table 3.Frequency Distribution of Respondents Characteristics According to,

Occupation at Puskesmas Lamongan $(n=43)$

\begin{tabular}{ccc}
\hline Profession & Frequency & \% \\
\hline Work & 26 & 60.5 \\
Does not work & 17 & 39.5 \\
Total & $\mathbf{4 3}$ & $\mathbf{1 0 0}$ \\
\hline
\end{tabular}

The characteristics of respondents related to work showed that most of the respondents worked as many as 26 people $(60.5 \%)$.

2. Bivariate Analysis

a. Relationship between Age of Respondents and Implementation of Early Initiation of Breastfeeding

The relationship between age and early initiation of breastfeeding implementation in mothers after statistical tests can be seen in Table 4.

Table 4. Table of the Relationship Between Age and Implementation of Early Initiation of Breastfeeding in Puskesmas Lamongan

\begin{tabular}{|c|c|c|c|c|c|c|c|}
\hline \multirow{3}{*}{ Age } & \multicolumn{4}{|c|}{$\begin{array}{c}\text { Early initiation of } \\
\text { breastfeeding implementation }\end{array}$} & \multirow{2}{*}{\multicolumn{2}{|c|}{ Total }} & \multirow{3}{*}{$P$ Value } \\
\hline & \multicolumn{2}{|c|}{ Yes } & \multicolumn{2}{|c|}{ Not } & & & \\
\hline & $\sum$ & $\%$ & $\sum$ & $\%$ & $\sum$ & $\%$ & \\
\hline$\leq 27$ years & 11 & 57.9 & 8 & 42.1 & 19 & 100 & \\
\hline $\begin{array}{l}>27 \\
\text { Years }\end{array}$ & 14 & 58.3 & 10 & 41.7 & 24 & 100 & 0.977 \\
\hline Total & 25 & 58.1 & 18 & 41.9 & 43 & 100 & \\
\hline
\end{tabular}

Table 4 shows that there were 11 respondents in the $\leq 27$ years age group who implemented early initiation of breastfeeding (57.9\%) and 8 people who did not implement early initiation of breastfeeding (42.1\%). Respondents in the age group > 27 years who implemented early initiation of breastfeeding were 14 people $(58.3 \%)$ and 10 people who did not implement early initiation of breastfeeding (41.7\%).

Based on the Chi Square statistical test between the age variable and the early initiation of breastfeeding implementation variable, the $p$ value was 0.977 ( $p>0.05)$.

\section{b. Relationship between Respondent Education and IMD Implementation}

The results of testing the relationship between education and the implementation of early initiation of breastfeeding in mothers after statistical tests can be seen in table 5 .

Table 5. Table of Relationship Between Education and Implementation of early initiation of breastfeeding

\begin{tabular}{lcccccccc}
\hline \multirow{2}{*}{ Education } & \multicolumn{4}{c}{ IMD implementation } & \multicolumn{2}{c}{ Total } & \multirow{2}{*}{ Y Value } \\
& $\sum$ & & $\%$ & $\sum$ & $\%$ & $\sum$ & $\%$ & \\
\hline SD & 3 & 33.3 & 6 & 66. & 9 & 100 & \\
\multirow{2}{*}{ Junior High } & 4 & 66.7 & 2 & 33. & 6 & 100 & \\
& & & & & 3 & & &
\end{tabular}




\section{STRADA Jurnal Ilmiah Kesehatan}

DOI: $10.30994 /$ sjik.v9i2.443

ISSN: 2252-3847 (print); 2614-350X (online)

Vol.9 No.2 November 2020 Page.1151-1159

$\begin{array}{lcccccc}\text { High school } & 14 & 58.3 & 10 & 41 . & 24 & 100 \\ \text { PT } & 4 & 100 & 0 & 0 & 4 & 100 \\ \text { Total } & 25 & 58.1 & 18 & 41 . & 43 & 100 \\ & & & & 9 & \end{array}$

Table 5 shows that the most respondents who implemented IMD were in the PT category, namely $(100 \%)$.

Based on the Chi Square statistical test between the education variables and the implementation of early initiation of breastfeeding, the $p$ value is $0.149(p>0.05)$.

c. Relationship between Knowledge about early initiation of breastfeeding plementation of early initiation of breastfeeding in mothers after statistical tests can be seen in Table 7.

Table 7. Table of Relationships Between Knowledge and Implementation of IMD

\begin{tabular}{lccccccc}
\hline \multirow{2}{*}{ Knowledge } & \multicolumn{3}{c}{ IMD implementation } & \multicolumn{2}{c}{ Total } & P value \\
& $\sum$ & $\%$ & $\sum$ & $\%$ & $\sum$ & $\%$ & \\
\hline Good $(>76-$ & 20 & 87 & 3 & 13 & 23 & 100 & \\
$\begin{array}{l}100 \%) \\
\text { Enough (56- }\end{array}$ & 3 & 27.3 & 8 & 72.7 & 11 & 100 & 0,000 \\
$75 \%)$ & 2 & 22.2 & 7 & 77.8 & 9 & 100 & \\
Less $(\leq 55 \%)$ & 25 & 58.1 & 18 & 41.9 & 43 & 100 & \\
Total & & & & & & & \\
\hline
\end{tabular}

Table 7 shows that respondents who had good knowledge and implemented IMD were 20 people (87\%) while respondents who had good knowledge but did not implement IMD were 3 people (11\%). Respondents who lack knowledge and implement IMD as many as 2 people $(22.2 \%)$ while respondents who lack knowledge and do not implement IMD as many as 7 people $(77.8 \%)$.

Based on the Chi Square statistical test between the variable maternal knowledge about breastfeeding and the IMD implementation variable, the $p$ value was $0.000(\mathrm{p}<0.05)$.

\section{d. Relationship between Attitudes and Implementation of IMD}

The relationship between attitudes towards the tradition of breastfeeding and supplementary food on the implementation of IMD in mothers after statistical tests can be seen in Table 8 .

Table 8.Table of the Relationship Between Attitudes Toward the Tradition of

Breastfeeding and Supplementary Food and the Implementation of IMD at Puskesmas Lamongan

\begin{tabular}{|c|c|c|c|c|c|c|c|}
\hline \multirow{3}{*}{$\begin{array}{l}\text { Attitudes Towards } \\
\text { the tradition of } \\
\text { breastfeeding and } \\
\text { supplementary food }\end{array}$} & \multicolumn{4}{|c|}{ IMD implementation } & \multirow{2}{*}{\multicolumn{2}{|c|}{ Total }} & \multirow[t]{3}{*}{ P value } \\
\hline & & es & & & & & \\
\hline & $\sum$ & $\%$ & $\sum$ & $\%$ & $\sum$ & $\%$ & \\
\hline Good (> 9) & 19 & 67.9 & 9 & 32.1 & 28 & 100 & 0.078 \\
\hline
\end{tabular}




\section{STRADA Jurnal Ilmiah Kesehatan}

DOI: $10.30994 /$ sjik.v9i2.443

ISSN: 2252-3847 (print); 2614-350X (online)

Vol.9 No.2 November 2020 Page.1151-1159

\begin{tabular}{lcccccc} 
Not good $(<9)$ & 6 & 40 & 9 & 60 & 15 & 100 \\
Total & 25 & 58.1 & 18 & 41.9 & 43 & 100 \\
\hline
\end{tabular}

Table 8 shows that respondents who have good attitudes and implement IMD are 19 people (67.9\%) while respondents who have poor attitudes towards breastfeeding and implementing IMD are 6 people (40\%).

Based on the Chi Square statistical test between the variable mother's attitude towards the tradition of breastfeeding and the IMD implementation variable, the $\mathrm{p}$ value was $0.078(\mathrm{p}>0.05)$.

\section{e. Relationship between Family Support and IMD}

The relationship between family support and exclusive breastfeeding for mothers after statistical tests can be seen in Table 9.

Table 9. Table of Relationship Between Family Support and Implementation of IMD in Lamongan Health Center

\begin{tabular}{lccccccc}
\hline \multirow{2}{*}{ Family support } & \multicolumn{4}{c}{ IMD implementation } & \multicolumn{2}{c}{ Total } & \multirow{2}{*}{ P value } \\
& $\sum$ & \% & $\sum$ & \% & $\sum$ & \% & \\
\hline Support $(>11)$ & 21 & 72.4 & 8 & 27.6 & 29 & 100 & \\
Not support $(\leq 11)$ & 4 & 28.6 & 10 & 71.4 & 14 & 100 & 0.006 \\
Total & 25 & 58.1 & 18 & 41.9 & 43 & 100 & \\
\hline
\end{tabular}

Table 9 shows that respondents who received support from their families and implemented IMD were 21 people $(72.4 \%)$ while respondents who received support from their families but did not implement IMD were 8 people $(27.6 \%)$. Respondents who did not get support from their families and implemented IMD were 4 people $(28.6 \%)$ while respondents who did not receive support from their families and did not implement IMD were 10 people $(71.4 \%)$.

Based on the Chi Square statistical test between the variable family support and the implementation of IMD, the $p$ value was $0.006(\mathrm{p}<0.05)$.

\section{DISCUSSION}

The results of the bivariate analysis between the age of the respondent and the implementation of the IMD showed $p=0.977$ ( $p>0.05$ ). This means that there is no relationship between maternal age and IMD implementation. The age period between 2035 years is a good period for childbirth. This is because at that age the mother is both physically and psychologically mature, so that if you have a baby you will be able to take good care of her. If the woman is less than 20 years old, the woman is still growing, from the biological factors it is ready, but the psychological aspect is not yet mature. Likewise, if the breastfeeding mother is more than 35 years of age, health problems often arise with complications. The results of the study explaining that the mother's age $>27$ years did not perform BMI (41.7\%) in accordance with the theory that the age period between 20-35 years is a good period for childbirth. This is because at that age the mother is both physically and psychologically mature, so that if you have a baby you will be able to take good care of her. Health problems often arise with complications at the age of $>35$ years so that IMD is not done. The mother's age determines maternal health because it relates to conditions of pregnancy, childbirth and childbirth, as well as how to care for and breastfeed her baby. Mothers who are less than 20 years old are still immature and are not 


\section{STRADA Jurnal Ilmiah Kesehatan}

DOI: $10.30994 /$ sjik.v9i2.443

ISSN: 2252-3847 (print); 2614-350X (online)

Vol.9 No.2 November 2020 Page.1151-1159

physically and socially ready to face pregnancy, childbirth, and breastfeeding for their babies. Whereas at the age of 35 years and over where hormone production is relatively reduced, the lactation process decreases, while at the age of 20 years and under, the development of physical, psychological (Aryani, 2018).

Based on the Chi Square statistical test between the education variables and the implementation of IMD, the $p$ value is 0.149 ( $p>0.05$ ). Most respondents who carry out IMD are in the PT category, namely $(100 \%)$. Education is a process of changing attitudes and behavior of a person or group of people who are endeavored to mature humans through teaching and training efforts, process of actions and ways of educating. Through education a person will get a series of knowledge that will be useful for him. The lower level of mother's education has an effect on the lack of basic thinking skills to make decisions, especially in implementing IMD (Assriyah et al., 2020). Women with higher education tend to pay more attention to the health of themselves and their families. With higher education, it will have an impact on a more open mindset such as breastfeeding from an early age through IMD. The frequency of breastfeeding was higher in educated women. Educated mothers are more aware of the physiological and psychological benefits, and are more motivated to obtain information, making it more likely to perform IMD than the less educated (Aryani, 2018).

Based on the Chi Square statistical test between the variable maternal knowledge about breastfeeding and the IMD implementation variable, the p value was $0.000(\mathrm{p}$ $<0.05$ ). There is a significant relationship between knowledge and implementation of IMD. The majority of mothers who carry out IMD have good knowledge. According to Green's theory, behavior is influenced by 3 main factors where one of the predisposing factors is knowledge. This result is in line with the theory which states that knowledge or cognition is a very important domain in shaping one's actions. From experience and research it is evident that behavior based on knowledge is more durable than behavior that is not based on knowledge. Knowledge is an important domain in determining behavior. Behavior based on knowledge, awareness and positive attitude will last longer. Good knowledge will make it easier for someone to change behavior, including in the practice of breastfeeding. Mother's behavior to provide exclusive breastfeeding is caused by factors that cause behavior, one of which is knowledge, where this factor becomes the basis or motivation for individuals to make decisions (Assriyah et al., 2020). Real actions can form an attitude, so supporting factors or enabling conditions are needed such as personal experience, influence of other people who are considered important (family), social and cultural influences, advertisements from electronic media or mass media, educational and religious institutions, emotional influence, education, socio-economic factors, physical readiness or health status, and psychological readiness or one's own psyche (Muthoharoh, 2020).

Based on the Chi Square statistical test, the variable attitudes of mothers towards the implementation of IMD obtained $p$ value 0.078 ( $>>0.05$ ). This shows that there is no relationship between attitude and implementation of IMD. Attitude is a tendency to behave in certain ways in social situations. Attitude refers to an individual's evaluation of various aspects of the social world as well as how that evaluation raises a feeling of liking or disliking individuals towards issues, ideas, other people, social groups and objects. Attitude is a reaction or response that is still closed from someone to a stimulus or object. The manifestation of attitude cannot be immediately seen, but can only be interpreted first from closed behavior. This attitude consists of three main components, namely: (1) Trust or belief, ideas and concepts about objects, meaning how one's beliefs and opinions or 


\section{STRADA Jurnal Ilmiah Kesehatan}

DOI: $10.30994 /$ siik.v9i2.443

ISSN: 2252-3847 (print); 2614-350X (online)

Vol.9 No.2 November 2020 Page.1151-1159

thoughts about objects, (2) Emotional life or evaluation of objects, meaning how the person's assessment (contained in emotional factors) towards objects, (3) Tendency to act, meaning attitude is a component that precedes overt action or behavior. Attitude is a courtesy to act or behave openly (Notoatmodjo, 2016).

The results of the Chi Square statistical test between the variable family support and the implementation of IMD obtained a p value of 0.006 ( $p<0.05)$, which means that there is a relationship between family support and the implementation of IMD. Breastfeeding mothers need both informational and emotional support from their families in carrying out early initiation of breastfeeding. Family is one of the factors of success or failure of breastfeeding because family support will increase the mother's self-confidence. The family also plays a role in determining the fluency of the let down reflex, which is strongly influenced by the mother's emotional state or feelings. Family support can be obtained from internal families such as husbands, siblings or can also be obtained from outside the nuclear family (Muthoharoh and Ningsih, 2019). Types of support include giving information, emotions and giving help. Information support includes part of the knowledge about the benefits of breastfeeding and how to breastfeed, emotional support including giving understanding, encouraging and loving, support support including giving physical assistance to be able to breastfeed her baby. Health workers must provide counseling in providing information regarding early initiation of breastfeeding given during pregnancy checks, especially for husbands and parents and more convincing to families so that mothers are willing to initiate early breastfeeding that early initiation of breastfeeding is important and has a positive impact on the baby and the mother, except for mothers who experience complications that must be treated quickly, for example, mothers experience bleeding (Adiesti and Diana, 2016).

\section{CONCLUSION}

There was a significant relationship between knowledge and the implementation of early breastfeeding initiation ( $\mathrm{p}$-value $=0,000$ ), there was a relationship between family support and implementation of early breastfeeding initiation ( $\mathrm{p}$ value $=0.006$ ). There was no relationship between age and implementation of early breastfeeding initiation ( $\mathrm{p}$ value $=0.977$ ), there was no relationship between education and implementation of early breastfeeding initiation ( $\mathrm{p}$ value $=0.149$ ), there was no relationship between attitude and implementation of early breastfeeding initiation ( $\mathrm{p}$ value $=0.078$ ).

\section{REFERENCES}

Adiesti, F. and Diana, S. (2016) 'Dukungan Keluarga Dengan Pelaksanaan Inisiasi Menyusui Dini Pada Ibu Post Partum Di BPS Sri Silasmiati,SST Desa Wonoayu, Pilang Kenceng Madiun', Prosiding Seminar Nasional Sains Dan Teknologi Fakultas Teknik, 1(1), pp. 1-4.

Ali, F. et al. (2020) 'Prevalence and factors associated with timely initiation of breastfeeding in Kilimanjaro region, northern Tanzania: a cross-sectional study', International Breastfeeding Journal. International Breastfeeding Journal, 20(1), p. 505. doi: 10.1186/s12884-020-03209-y.

Aryani, N. (2018) 'Faktor-faktor yang Berhubungan dengan Inisiasi Menyusu Dini di Wilayah Kerja Puskesmas Satelit Bandar Lampung', Jurnal Kesehatan Panca Bhakti Lampung, VI(1), pp. 31-51. 


\section{STRADA Jurnal Ilmiah Kesehatan}

DOI: $10.30994 /$ siik.v9i2.443

ISSN: 2252-3847 (print); 2614-350X (online)

Vol.9 No.2 November 2020 Page.1151-1159

Asmarani, A. (2019) 'Pengaruh Inisiasi Menyusu Dini (IMD) Terhadap Jumlah Darah Pada Ibu 2 Jam Post Partum DI BPM Marfuah Desa Rambutan Kabupaten Banyuasin Tahun 2019', Jurnal Kesehatan dan Pembangunan, 7(20), pp. 10-15.

Assriyah, H. et al. (2020) 'Hubungan Pengetahuan, Sikap, Umur, Pendidikan, Pekerjaan, Psikologis, Dan Inisiasi Menyusui Dini Dengan Pemberian Asi Eksklusif Di Puskesmas Sudiang', Jurnal Gizi Masyarakat Indonesia: The Journal of Indonesian Community Nutrition, 9(1), pp. 30-38. doi: 10.30597/jgmi.v9i1.10156.

Bbaale, E. (2014) 'Determinants of early initiation, exclusiveness, and duration of breastfeeding in Uganda', Journal of Health, Population and Nutrition, 32(2), pp. 249-260. doi: 10.3329/jhpn.v32i2.2619.

Faisal, A., Joserizal, S. and Hirowati, A. (2019) 'Pelaksanaan Program Inisiasi Menyusu Dini Di Wilayah Kerja Puskesmas Lubuk Buaya Kecamatan Koto Tangah’, Jurnal Kesehatan Andalas, 8(4), pp. 1-9.

Muthoharoh, H. (2017) 'Gambaran Pengetahuan Ibu Bersalin Tentang Inisiasi Menyusu Dini (IMD) DI Desa Gempol Pading Kecamatan Pucuk Lamongan', Jurnal Midpro, 9(2), pp. 14-19.

Muthoharoh, H. (2018) 'Hubungan Pelaksanaan IMD (Inisiasi Menyusu Dini) Dan Pemberian ASI Eksklusif Pada Bayi Usia 7-12 Bulan di Desa Payaman', in Seminar Nasional Unisla, pp. 231-234.

Muthoharoh, H. (2020) 'Pemberian Makanan Pendamping Air Susu Ibu Secara Dini Pada Bayi Usia 0-6 Bulan Berdasarkan Pengetahuan Keluarga', Window of Health: Jurnal Kesehatan, 3(3), pp. 259-266.

Muthoharoh, H. and Ningsih, E. S. (2019) 'Hubungan Dukungan Keluarga Dengan Keberhasilan Pemberian ASI Eksklusif pada Bayi Usia 7-12 Bulan di Desa Payaman', Journal for Quality in Women's Health, 2(1), pp. 1-6. doi: 10.30994/jqwh.v2i1.19.

Notoatmodjo, S. (2016) Metodologi Penelitian Kesehatan. Jakarta: Rineka Cipta.

Sari, D. N. and Ambarwati, T. V. (2020) 'Gambaran Faktor Internal Dan Eksternal Pelaksanaan Inisiasi Menyusu Dini (IMD) Di Salah Satu Puskesmas Kabupaten Bandung Periode Maret-April 2019', Jurnal Asuhan Ibu dan Anak, 5(1), pp. 914. doi: $10.33867 /$ jaia.v5i1.144.

Sukarti, N. N. et al. (2020) 'Hambatan Keberhasilan Pelaksanaan Inisiasi Menyusu Dini ( IMD ) pada Ibu Bersalin di Rumah Sakit Umum Pusat Sanglah Denpasar', Jurnal Ilmiah Kebidanan: The Journal of Midwifery, 8(1), pp. 40-53.

Sulistianingsih, A. (2020) 'Faktor yang Berpengaruh terhadap Konsentrasi Pengemudi', Jurnal Ilmiah Kesehatan, IX(1), pp. 33-40. doi: 10.25104/warlit.v29i1.318. 